\title{
Gastrointestinal Motility in Health and Disease
}

\author{
H. L. Duthie \\ Piero Biancani \\ Michael Zabinski \\ Fairfield University, zabinski@fairfield.edu \\ Morris D. Kerstein \\ Jose Behar
}

Follow this and additional works at: https://digitalcommons.fairfield.edu/engineering-books Copyright 1978 Springer Science+Business Media New York The author post-print has been archived here with permission from the copyright holder.

\section{Recommended Citation}

Duthie, H. L.; Biancani, Piero; Zabinski, Michael; Kerstein, Morris D.; and Behar, Jose, "Gastrointestinal Motility in Health and Disease" (1978). Engineering Faculty Book Gallery. 37.

https://digitalcommons.fairfield.edu/engineering-books/37

This item has been accepted for inclusion in DigitalCommons@Fairfield by an authorized administrator of DigitalCommons@Fairfield. It is brought to you by DigitalCommons@Fairfield with permission from the rightsholder(s) and is protected by copyright and/or related rights. You are free to use this item in any way that is permitted by the copyright and related rights legislation that applies to your use. For other uses, you need to obtain permission from the rights-holder(s) directly, unless additional rights are indicated by a Creative Commons license in the record and/or on the work itself. For more information, please contact digitalcommons@fairfield.edu. 
COMPARISON OF MECHANICAL CHARACTERISTICS OF THE LOWER ESOPHAGEAL SPHINCTER AND PYLORIC SPHINCTER

Biancani, P., Zabinski, M.P., Kerstein, M.D., and Behar, J.

Departmen: of Medicine, Yale University School of Medicine, New Haven, C.T. 06510, Department of Physics, Fairfield University, Fairfield, C.T. 06430 , and Brown University, Providence, R.I. 02902 USA.

Running Head: LOWER ESOPHAGEAL AND PYLORIC SPHINCTERS

Mail Proofs to: P. Biancani Department of Internal Medicine Yale University School of Medicine 333 Cedar Street New Haven, C.T. 06510 USA 
Adult cats of either sex were anesthetized with Ketamine hydrochloride and the gastroesophageal and gastroduodenal junctions exposed. The in vivo lower esophageal sphincter (LES) and pyloric sphincter (PS) were identified with pressure measuring probes having a perfused side opening adjacent to a metal plug obstructing the distal tip. With the catheter's side opening located at the point of high pressure a pin was placed on the outer surface under fluoroscopy to coincide with the proximal end of the metal plug. In this manner, the precise location of the side opening was identified on the outer surface and a suture was used to mark the location of the LES and PS high pressure points. The esophagus, stomach, and duodenum were removed together and pinned on a wax block and stretched to their respective in vivo lengths. Consecutive rings were cut from the gastroesophageal and pyloric regions with blades held in a block, $1.75 \mathrm{~mm}$ apart. The rings were suspended between two platinum hooks in a muscle bath. The lower hook was rigidly attached to the bottom of the muscle bath. The upper hook was attached to a force transducer (UC-2 cell Statham Instruments) which was mounted on a micrometer stage (Edmund Scientific Co.). The stretch applied to the rings was measured by the distance between the hooks. After mounting, the rings were allowed to equilibrate for 30 minutes in Tyrode solution at $37^{\circ} \mathrm{C}$.

After the initial period of equilibration in Tyrode solution, the forces developed by the rings were recorded (basal force). This solution was then replaced by Tyrode solution to which potassium chioride (140 mM) had been added. This solution depolarized the muscle causing a sustained 
contraction (total force). After 15 minutes in $\mathrm{KCl}$ solution, it was replaced by calcium-free Tyrode solution containing 5 mM EDTA which binds extra-cellular free calcium causing the muscle to relax (passive force). The force developed by contraction of the muscle (active force) is the difference between total and passive forces. This sequence was repeated at various lengths of stretch to obtain force-length curves.

With increasing levels of stretch, the active force developed by each ring increased at first, peaked at the length of maximum active force development (MAF), and subsequentiy decreased.

The LES ring identified by the suture exhibits the steepest basal force-length curve. This ring also exhibits the highest active and total force-length curves with potassium-chloride stimulation; but its passive force-length curve does not differ from those of adjacent esophageal rings. Fic I - >

The maximum active forces for consecutive rings from the gastroesophageal junction are compared in Figure 1. The passive forces are shown at specific length of stretch $(28 \mathrm{~mm})$ which corresponds to the length of maximal active force deveropment for the LES ring. At MAF, the strip corresponding to the LES high pressure point exhibits the naximum active force. Its passive force is the same as for the adjacent rings.

The PS ring, identified by the suture, exhibits the highest passive, basal, and total forces at all levels of stretch when compared with adjacent rings. The length of MAF, is lower in the pylorus than in the antrum and duodenum. The maximum active force of the PS ring is higher than the MAF of the duodenal rings, but not significantly higher than the 
antral rings (Figure 1). The passive force at a specific length of stretch $(14 \mathrm{~mm})$ which corresponds to the maximal active force development for the pyloric ring is also shown in Figure 1, and is highest for the pyloric ring.

It is concluded that in the LES region no differences in passive force are observed and the high total force observed in the LES ring is due to a higher active force than that of adjacent rings. In contrast, the higher total force of the pyloric ring is due to higher passive force which maybe caused by the presence of stricture rather than to higher active forces. 
Acknowledgements: This research was supported by NIH Grant R01 AM 16021.

Legend:

Figure 1: The left panel shows the maximum active force developed by adjacent rings from the LES region. The passive forces at $28 \mathrm{~mm}$ stretch are shown by the lower curve. The right panel shows the maximum active force developed by adjacent rings from the pyloric region. The passive forces at $14 \mathrm{~mm}$ stretch are shown by the lower curve. 
خे
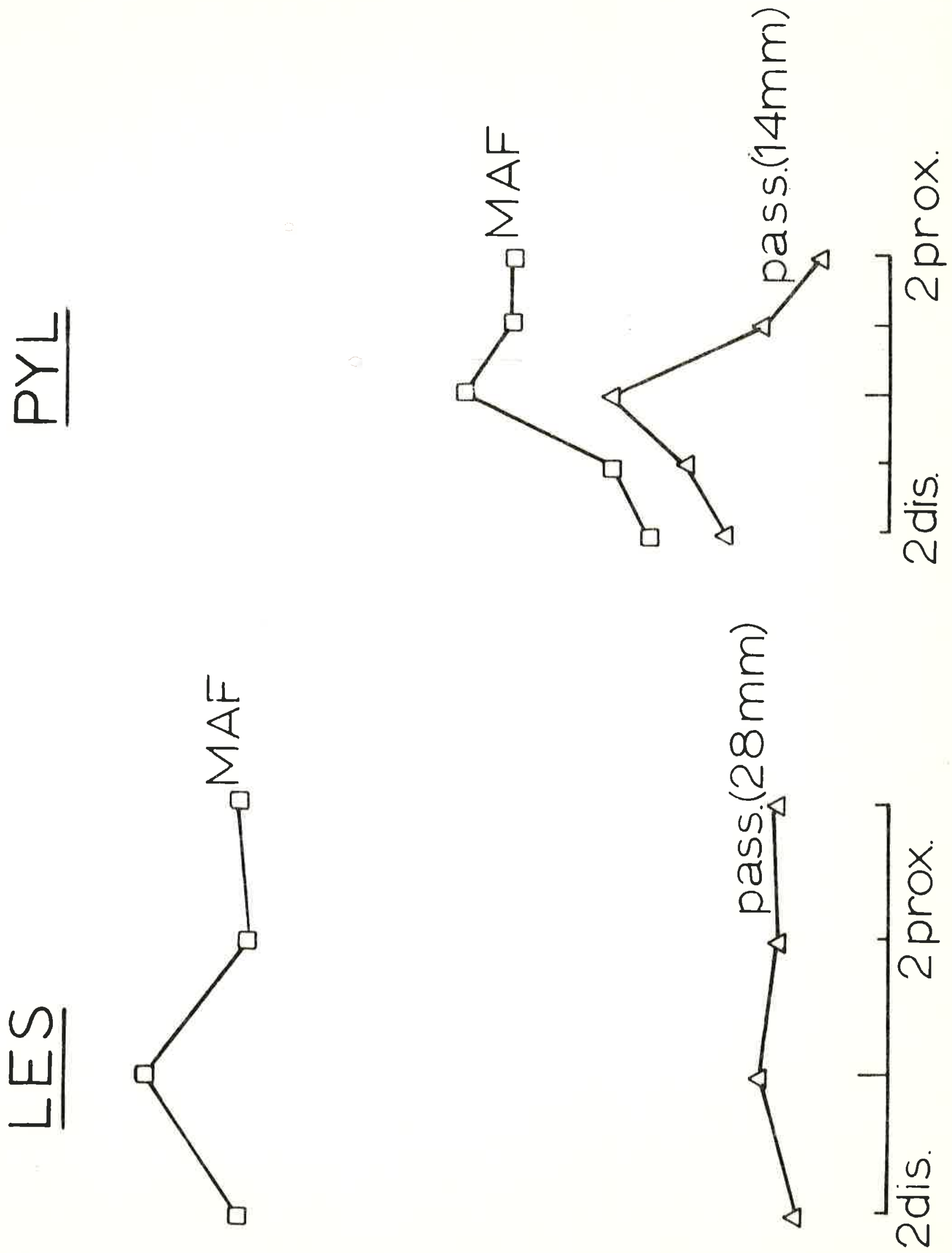

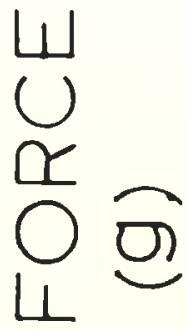

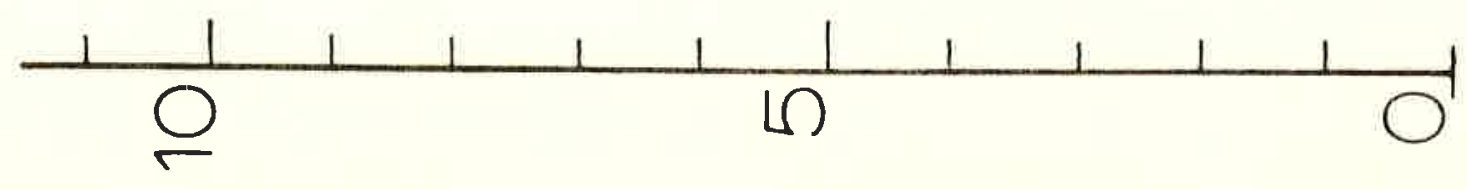

